\title{
10. PRELIMINARY RESULTS FROM POLLEN ANALYSES OF SELECTED SAMPLES FROM LEG $145^{1}$
}

\author{
Linda E. Heusser ${ }^{2}$ and Joseph J. Morley ${ }^{2}$
}

\begin{abstract}
The results from preliminary analyses of 50 samples from Sites 881,883 , and 887 show variations in pollen assemblages that appear to reflect vegetational and climatic changes in northeast Asian and northwest North American subarctic environments. Reliable interpretation of these pollen data, however, is precluded by the minimal amount of pollen in all the samples, and by the presence of large amounts of reworked material, particularly in samples from Site 887.
\end{abstract}

\section{INTRODUCTION}

Although the value of marine pollen in providing terrestrial late Neogene paleoclimatic data has been demonstrated in lower latitudes (Dupont and Agwu, 1992; Heusser, 1992a), the limited use of pollen from high-latitude marine sediments in paleoenvironmental reconstructions is a result, at least in part, of the numerous environmental limitations of the arctic environment (e.g., the relatively restricted amount of continuous vegetation). Nevertheless, investigations of arctic marine pollen have expanded since 1985, particularly in the Northwest Atlantic region (de Vernal et al., 1987; Aksu et al., 1992). Previous studies of pollen in North Pacific, Bering Sea, and Arctic Ocean sediments indicated that pollen concentrations in Leg 145 sediments would be marginal (P. Colinvaux, pers. comm., 1973; Heusser and Balsam, 1977; Nelson, unpubl. data, 1978; Sancetta et al., 1985). The obvious problems associated with a study of this type were offset, however, by the potential value of obtaining Neogene paleoclimatic data from subarctic Siberia and Alaska.

Initially, one site in the Gulf of Alaska, Ocean Drilling Program (ODP) Site $887\left(54^{\circ} 22^{\prime} \mathrm{N}, 148^{\circ} 27^{\prime} \mathrm{W}, 3643 \mathrm{mbsf}\right)$, was selected for pollen analyses because of its comparatve proximity to land, as well as its relation to aeolian and marine pollen transport vectors (Fig. 1). Pollen data were expected to complement the anticipated high-resolution marine and continental (e.g., ice-rafted debris) proxy paleoclimate data by providing a reconstruction of the response of vegetation and implied terrestrial climatic change to Neogene glaciation and global climate change. The poor quality of the pollen recovered in the first set of samples processed from Site 887 prompted us to examine selected Neogene samples from Holes $883 \mathrm{~B}\left(51^{\circ} 11^{\prime} \mathrm{N}, 167^{\circ} 46^{\prime} \mathrm{W}, 2396 \mathrm{mbs}\right)$, $881 \mathrm{C}\left(47^{\circ} 6^{\prime} \mathrm{N}, 161^{\circ} 29^{\prime} \mathrm{W}, 5541 \mathrm{mbsf}\right)$, and $881 \mathrm{D}\left(47^{\circ} 6^{\prime} \mathrm{N}, 161^{\circ} 29^{\prime} \mathrm{W}\right.$, 5542 mbsf) (Fig. 1). Biostratigraphy used in this paper is based on Morley et al. (this volume), and Morley and Nigrini (this volume).

\section{METHODS AND RESULTS}

Approximately 50 samples, subsets of $5 \mathrm{~cm}$ increments analyzed for radiolaria (Morley et al., this volume; Morley and Nigrini, this volume), were processed using standard palynological techniques (Heusser and Stock, 1984). Sample size ranged from 1 to $16 \mathrm{~g}$ dry weight. The prepared samples were stained with Safranin-O to aid in identifying reworked pollen (Stanley, 1966). Processing the siliceous

\footnotetext{
' Rea, D.K., Basov, L.A., Scholl, D.W., and Allan, J.F. (Eds.), 1995. Proc. ODP, Sci. Results, 145: College Station, TX (Ocean Drilling Program).

${ }^{2}$ Lamont-Doherty Earth Observatory, Columbia University, Palisades, NY 10987, U.S.A., and Heusser and Heusser, Clinton Road, Tuxedo, NY 10987, U.S.A.
}

silty clays from Site 887 was particularly time-consuming and not altogether satisfactory as the residues contained large amounts of undigested siliceous material, even after extended treatment with hydrofluoric acid. As expected, pollen recovery from all samples, even samples as large as $16 \mathrm{~g}$, was minimal, yielding less than a drop of residue. Pollen recovery in samples $<4 \mathrm{~g}$ was possible in only a few instances. Even though pollen sums were low, concentration (grains/g dry weight sediment) and percentages of pollen (the total of apparently autochthonous pollen) and percentages of spores (based on the sum of total pollen and spores) were calculated so that we could have a standard means of comparing samples (Tables 1-3).

Preservation of pollen was highly variable, with most pollen grains showing some evidence of diagenetic alteration (e.g., differential stain acceptance and corrosion). This presented a major problem in differentiating autochthonous and allochthonous (reworked) pollen and spores because all of the pollen and spores examined were morphologically similar to contemporaneous pollen types. In samples from Hole $887 \mathrm{~A}$, separation of pollen (presumably derived from glaciogenic erosion of polliniferous Neogene deposits in the Alaska Range (Hamilton et al., 1986) was essentially a subjective judgment based on differential stain acceptance, "flattening," and corrosion observed in each grain. Conservative estimates of pollen grains from older Neogene sediments were usually $>50 \%$ in Quaternary samples from Site 887. Reworked pollen and spores were generally less abundant in sediments from northwest Pacific Sites 881 and 883, with reworked pollen grain percentages $<10 \%$ in Pliocene samples from Site 881 .

Subarctic Pacific pollen concentrations (pollen grains tentatively identified as autochthonous/g dry weight sediment [gdws]) range from 0 to 500 grains (Tables 1-3). Pollen is most abundant in Quaternary sediments deposited on the Patton-Murray Seamount; however, we suspect that the higher concentrations of pollen in sediments from Site 887 may reflect pollen grains not recognized as reworked. Pollen concentrations from Pliocene samples from Hole $887 \mathrm{~A}$ and from samples from cores taken at Sites 883 and 881 are usually 100 grains/ gdws or less, except for one sample (Sample 145-881D-6H-CC; 212 mbsf) in which concentration was $400 / g d w s$.

The composition of pollen assemblages from Hole 887A (Fig. 2 and Table 2) reflects various boreal plant communities of the subarctic, including coastal forests with Sitka spruce, shrub thickets with alder and birch, as well as muskeg and tundra communities of sedge, grass, heath, and Sphagnum moss (Hulten, 1968). In both Quaternary and Pliocene samples from the Gulf of Alaska, Alnus (alder) and Betula (birch) are the dominant indigenous pollen types (Heusser, 1985; Heusser and Balsam, 1977). Although some Pinus (pine) pollen may represent regional vegetation, percentages of Pinus and possibly, to a lesser degree, all pollen in sediments deposited at Site 887 and in the other two sites examined in this study undoubtedly reflect long-distance fluviomarine and aeolian transport (Heusser, 1978). 
Table 1. Pollen data, percentages, and concentration (grains/gdws) from Site 881.

\begin{tabular}{|c|c|c|c|}
\hline $\begin{array}{l}\text { Hole: } \\
\text { Core, section: } \\
\text { Interval }(\mathrm{cm}) \text { : } \\
\text { Depth (mbsf): }\end{array}$ & $\begin{array}{c}881 \mathrm{C} \\
1 \mathrm{H}-1 \\
110-111 \\
110\end{array}$ & $\begin{array}{c}881 \mathrm{D} \\
6 \mathrm{H}-\mathrm{CC} \\
\mathrm{CC} \\
212 \\
\end{array}$ & $\begin{array}{c}881 \mathrm{C} \\
27 \mathrm{X}-2 \\
20-21 \\
240 \\
\end{array}$ \\
\hline $\begin{array}{l}\text { Raw data } \\
\text { Pinus } \\
\text { Tsuga } \\
\text { Abies } \\
\text { Picea } \\
\text { Alnus } \\
\text { Betula } \\
\text { Ericaceae } \\
\text { Myrica } \\
\text { Quercus } \\
\text { Gramineae } \\
\text { Cyperaceae } \\
\text { Compositae } \\
\text { Chenopodiaceae }\end{array}$ & $\begin{array}{r}13 \\
0 \\
0 \\
2 \\
11 \\
10 \\
1 \\
0 \\
0 \\
6 \\
10 \\
20 \\
1\end{array}$ & $\begin{array}{r}21 \\
0 \\
0 \\
29 \\
10 \\
10 \\
0 \\
0 \\
3 \\
6 \\
5 \\
12 \\
11\end{array}$ & $\begin{array}{r}23 \\
1 \\
1 \\
9 \\
17 \\
11 \\
0 \\
2 \\
3 \\
9 \\
7 \\
7\end{array}$ \\
\hline $\begin{array}{l}\text { Total pollen } \\
\text { Polypodiaceae } \\
\text { Lycopodiaceae } \\
\text { Sphagnum }\end{array}$ & $\begin{array}{r}74 \\
14 \\
5 \\
16\end{array}$ & $\begin{array}{r}97 \\
9 \\
5 \\
9\end{array}$ & $\begin{array}{r}91 \\
12 \\
1 \\
6\end{array}$ \\
\hline Total spores & 35 & 23 & 19 \\
\hline $\begin{array}{l}\text { Percentages } \\
\text { Pinus } \\
\text { Tsuga } \\
\text { Abies } \\
\text { Picea } \\
\text { Alnus } \\
\text { Betula } \\
\text { Ericaceae } \\
\text { Myrica } \\
\text { Quercus } \\
\text { Gramineae } \\
\text { Cyperaceae } \\
\text { Compositae } \\
\text { Chenopodiaceae } \\
\text { Polypodiaceae } \\
\text { Lycopodiaceae } \\
\text { Sphagnum }\end{array}$ & $\begin{array}{r}18 \\
0 \\
0 \\
3 \\
15 \\
14 \\
1 \\
0 \\
0 \\
8 \\
14 \\
27 \\
1 \\
13 \\
5 \\
15\end{array}$ & $\begin{array}{r}22 \\
0 \\
0 \\
30 \\
10 \\
10 \\
0 \\
0 \\
3 \\
6 \\
5 \\
12 \\
11 \\
8 \\
5 \\
8\end{array}$ & $\begin{array}{r}25 \\
1 \\
1 \\
10 \\
19 \\
12 \\
0 \\
2 \\
3 \\
10 \\
8 \\
8 \\
11 \\
1 \\
5\end{array}$ \\
\hline $\begin{array}{l}\text { Concentration (poll } \\
\text { Total GDWS } \\
\text { Pinus } \\
\text { Tsuga } \\
\text { Abies } \\
\text { Picea } \\
\text { Alnus } \\
\text { Betula } \\
\text { Ericaceae } \\
\text { Myrica } \\
\text { Quercus } \\
\text { Gramineae } \\
\text { Cyperaceae } \\
\text { Compositae } \\
\text { Chenopodiaceae } \\
\text { Polypodiaceae } \\
\text { Lycopodiaceae } \\
\text { Sphagnum }\end{array}$ & $\begin{array}{c}\text { grains/gd } \\
100 \\
1800 \\
0 \\
0 \\
300 \\
1500 \\
1400 \\
100 \\
0 \\
0 \\
800 \\
1400 \\
2700 \\
100 \\
1300 \\
500 \\
1500\end{array}$ & $\begin{array}{r}\text { lws) } \\
400 \\
8800 \\
0 \\
0 \\
12000 \\
4000 \\
4000 \\
0 \\
0 \\
1200 \\
2400 \\
2000 \\
4800 \\
400 \\
3200 \\
2000 \\
3200\end{array}$ & $\begin{array}{r}100 \\
2500 \\
100 \\
100 \\
1000 \\
1900 \\
1200 \\
0 \\
200 \\
300 \\
1000 \\
800 \\
800 \\
100 \\
1100 \\
100 \\
500\end{array}$ \\
\hline
\end{tabular}

Note: gdws = gram dry weight sediment.

Pollen from herbaceous vegetation (Gramineae [grass], Cyperaceae [sedge], Compositae, and Chenopodiacae) usually forms $~ 10 \%-25 \%$ of the pollen sum, and percentages of ferns (Polypodiaceae) range from $6 \%$ to $29 \%$.

The composition of Quaternary pollen assemblages from Site 883 (Fig. 3 and Table 3) compares favorably with that of boreal and subarctic vegetation and with contemporaneous pollen assemblages from northeast Asia (Hopkins et al., 1982; Grichuk, 1984; Morley and Heusser, 1991). As in the Gulf of Alaska, samples from these western north Pacific sites are dominated by Alnus and Betula; however, Picea is much more prominent in marine-sediments deposited off northeast Asia. Percentages of Picea reach $30 \%$ in a Pliocene sample from Hole 881D (Sample 145-881D-6H-CC) (Table 1). Pliocene pollen assemblages from Site 881 (Table 1) show changes in composition consistent with those previously described from Deep Sea Drilling Project Sites 438 and 440 (Heusser and Morley, 1993) and from terrestrial sites in northern Japan (Heusser, 1992a).

\section{DISCUSSION}

Concentrations of pollen in Neogene subarctic sediments of the North Pacific in Quaternary siliceous silty clays with mixed sediments or in Pliocene diatom oozes are several orders of magnitude lower than pollen concentrations in sediments deposited to the south (Heusser and Balsam, 1977). The low amount of pollen, which is comparable with that found in marine sediments deposited elsewhere in arctic marine settings (Mudie, 1985; de Vernal et al., 1987), undoubtedly reflects dilution by terrigenous detritus and biogenic silica (Kemp, 1975) as well as the comparatively low pollen production of subarctic vegetation.

Comparison of Quaternary samples from Holes 883B and 887A (Figs. 2 and 3; Tables 2 and 3) shows no clear glacial/interglacial variation in pollen concentrations or in the relative abundance of reworked pollen. Glacial/interglacial changes, however, are apparent in the composition of pollen assemblages at these two sites. Glacial samples (e.g., Samples 145-883B-1H-2, 75-79 cm [2.25 mbsf], and $-4 \mathrm{H}-4,75-79$ [32.15 mbsf]) are characterized by low amounts of arboreal pollen and by an abundance of subarctic shrubs (Alnus and Betula). In contrast, Picea and Pinus dominate interglacial samples (Samples 145-883B-1H-5, 75-78 cm [6.75 mbsf], and -3H-2, 75-79 $\mathrm{cm}$ [19.65 mbsf]). In the northeast Pacific, the abundance of Picea and Pinus characterizes full glacial pollen assemblages (Heusser and Morley, 1985). In our youngest sample from Hole 887A (Sample 145$887 \mathrm{~A}-1 \mathrm{H}-1,44-48 \mathrm{~cm}$ [0.45 mbsf]), forest taxa form $25 \%$ of the pollen sum and Sphagnum, an indicator of mesic tundra, is abundant (35\%). During the last glacial maximum (Sample 145-887A-1H-1, 120-123 $\mathrm{cm}[1.2 \mathrm{mbs}]$ ), forest representatives amount to $6 \%$ of the pollen sum.

The two Pliocene samples from Site 881 in the northwestern Pacific also show changes in the abundance of forest taxa (Table 1). At approximately $5 \mathrm{Ma}$ (Sample 145-881C-27X-2, 20-21 cm [240 mbsf]), pollen is present from warm-subtropical taxa that are now extinct in Japan, as are small amounts of temperate taxa such as Carya and Fagus. At $\sim 4 \mathrm{Ma}$ (Sample 145-881D-6H-CC [212 mbsf]), percentages of Picea increase from $\sim 10 \%$ to $30 \%$ of the pollen sum, and now-extinct Tertiary types are no longer present. These changes in the composition of Neogene pollen assemblages from the subarctic North Pacific are consistent with changes in correlative pollen assemblages onshore (Hopkins et al., 1982; Grichuk, 1984; Heusser and Morley, 1985; Heusser, 1992b; Oka and Igarashi, 1993).

\section{SUMMARY}

Initial evaluation of selected samples from cores recovered from Sites 881,883 , and 887 indicates a limited potential for future pollen stratigraphic and paleoclimatic studies. Although Neogene pollen data appear to be consistent with regional subarctic vegetation/climatic trends, reconstructions of vegetation based on this material would be suspect because of the scarcity of pollen at all three sites. Compounding this problem, sediments at Site 887 contain substantial amounts of recycled pollen, which are probably derived from glaciogenic erosion of the massive coal and lignite-bearing Neogene deposits onshore.

\section{REFERENCES*}

Aksu, A.E., Mudie, P.J., de Vernal, A., and Gillespie, H., 1992. Ocean-atmosphere responses to climatic change in the Labrador Sea: Pleistocene plankton and pollen records. Palaeogeogr., Palaeoclimatol., Palaeoecol., 92:124-137.

de Vernal, A., Hillaire-Marcel, C., Aksu, A.E., and Mudie, P.J., 1987. Palynostratigraphy and chronostratigraphy of Baffin Bay deep sea cores: climato-

\footnotetext{
- Abbreviations for names of organizations and publications in ODP reference lists follow the style given in Chemical Abstracts Service Source Index (published by American Chemical Society).
} 
stratigraphic implications. Palaeogeogr., Palaeoclimatol., Palaeoecol., 61:97-105.

Dupont, L.M., and Agwu, C.O.C., 1992. Latitudinal shifts of forest and savanna in N.W. Africa during the Brunhes Chron: further marine palynological results from Site M $16415\left(9^{\circ} \mathrm{N}, 19^{\circ} \mathrm{W}\right)$. Veget. Hist. Archaeobot., 1:163-175.

Grichuk, M.P., 1984. Changes in species composition of flora of northeastern Eurasia in the Late Cenozoic. In Kontrimavichus, V.I. (Ed.), Beringia in the Cenozoic Era: New Delhi (Amerind Publ. Co.), 188-200.

Hamilton, T.D., Reed, K.M., and Thorson, R.M. (Eds.), 1986. Glaciation in Alaska-The Geologic Record: Anchorage, AK (Alaska Geol. Soc.).

Heusser, C.J., 1985. Quaternary pollen records from the Pacific Northwest Coast: Aleutians to the Oregon-California border. In Bryant, V.M., Jr., and Holloway, R.G. (Eds.), Pollen Records of Late-Quaternary North American Sediments: Dallas, TX (Am. Assoc. of Stratigr. Palynol.), 141-165.

Heusser, L., 1978. Organic-walled microfossils: spores and pollen in the marine realm. In Haq, B.U., and Boersma, A. (Eds.), Introduction to Marine Micropaleontology: New York (Elsevier), 327-339.

Heusser, L., and Balsam, W.L., 1977. Pollen distribution in the Northeast Pacific Ocean. Quat. Res., 7:45-62.

Heusser, L.E., 1992a. Neogene palynology of Holes 794A, 795A, and 797B in the Sea of Japan: stratigraphic and paleoenvironmental implications of the preliminary results. In Pisciotto, K.A., Ingle, J.C., Jr., von Breymann, M.T., Barron, J., et al., Proc. ODP, Sci. Results, 127/128 (Pt. 1): College Station, TX (Ocean Drilling Program), 325-339.

1992b. Stratigraphic and paleoenvironmental implications of Neogene palynology of ODP Sites 794 and 797 in the Sea of Japan. In Tsuchi, R., and Ingle, J.C., Jr. (Eds.), Pacific Neogene: Environment, Evolution and Events: Tokyo (Univ. Tokyo Press), 3-13.

Heusser, L.E., and Morley, J.J., 1985. Pollen and radiolarian records from deep-sea core RC14-103: climatic reconstructions of Northeast Japan and Northwest Pacific for the last 90,000 years. Quat. Res., 24:60-72.
1993. Pliocene climate modes and mechanisms: new evidence from the western Pacific. Eos, 74:365.

Heusser, L.E., and Stock, C.E., 1984. Preparation techniques for concentrating pollen from marine sediments and other sediments with low pollen density. Palynology, 8:225-227.

Hopkins, D.M., Matthews, J.V., Jr., Schweger, C.E., and Young, S.B. (Eds.), 1982. Paleoecology of Bergingia: New York (Academic).

Hulten, E., 1968. Flora of Alaska and Neighboring Territories: Stanford, CA (Stanford Univ. Press).

Kemp, E.M., 1975. Palynology of Leg 28 drill sites, Deep Sea Drilling Project. In Hayes, D.E., Frakes, L.A., et al., Init. Repts. DSDP, 28: Washington (U.S. Govt. Printing Office), 599-623.

Morley, J.J., and Heusser, L.E., 1991. Late Pleistocene/Holocene radiolarian and pollen records from sediments in the Sea of Okhotsk. Paleoceanog. raphy, 6:121-131.

Mudie, P.J., 1985. Palynology of the Cesar Cores, Alpha Ridge. Pap.-Geol. Surv. Can., 84-22:149-174.

Oka, T., and Igarashi, Y., 1993. Plio-Pleistocene in the Toikanbetsu Tectonic Basin, northern Hokkaido: sedimentary facies and pollen stratigraphy. Chishitsugaku-Zasshi [J. Geol. Soc. Jpn.], 99:365-389.

Sancetta, C., Heusser, L., Labeyrie, L., Naidu, A.S., and Robinson, S.W., 1985. Wisconsin-Holocene paleoenvironment of the Bering Seas: evidence from diatoms, pollen, oxygen isotopes and clay minerals. Mar: Geol., 62:55-68.

Stanley, E.A., 1966. The problem of reworked pollen and spores in marine sediments. Mar. Geol., 4:397-408.

Date of initial receipt: 28 March 1994

Date of acceptance: 15 July 1994

Ms 145SR-106 


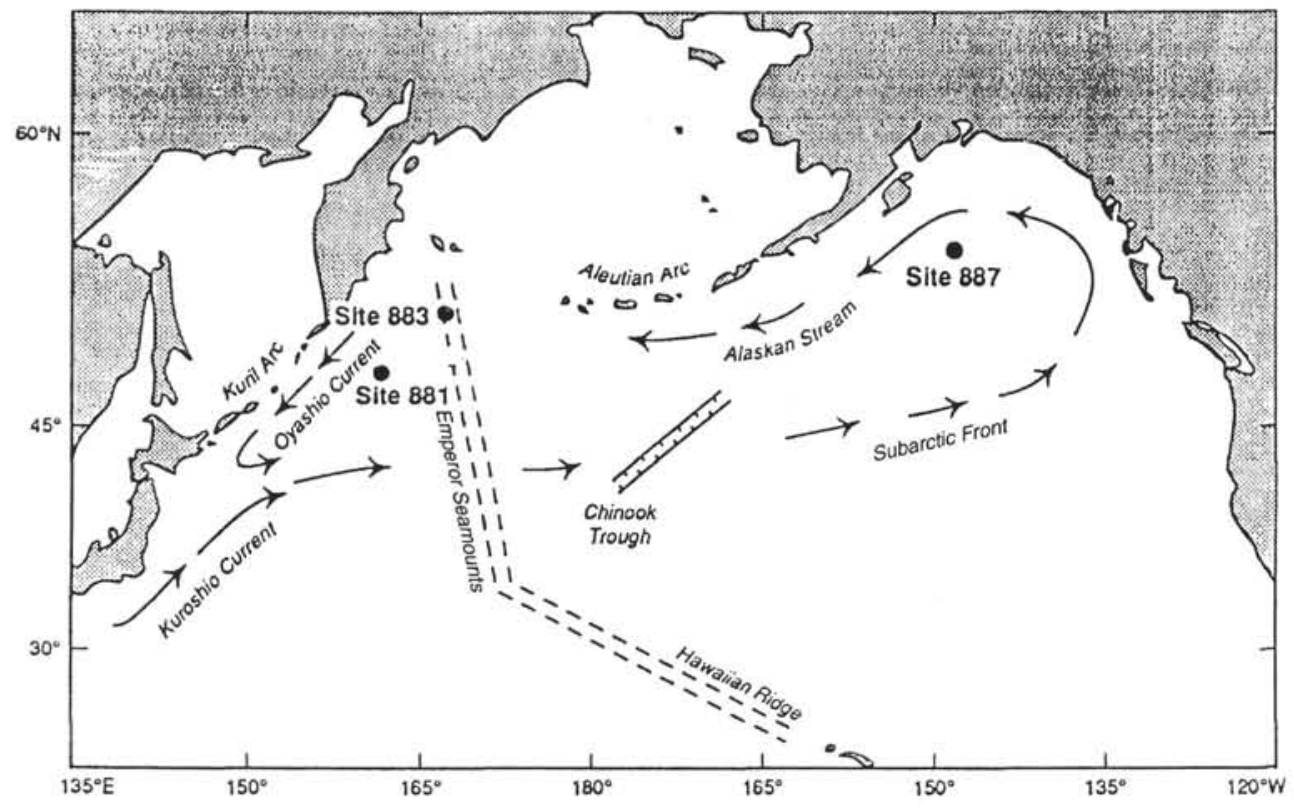

Figure 1. Map of the North Pacific showing locations of Sites 881,883 , and 887.

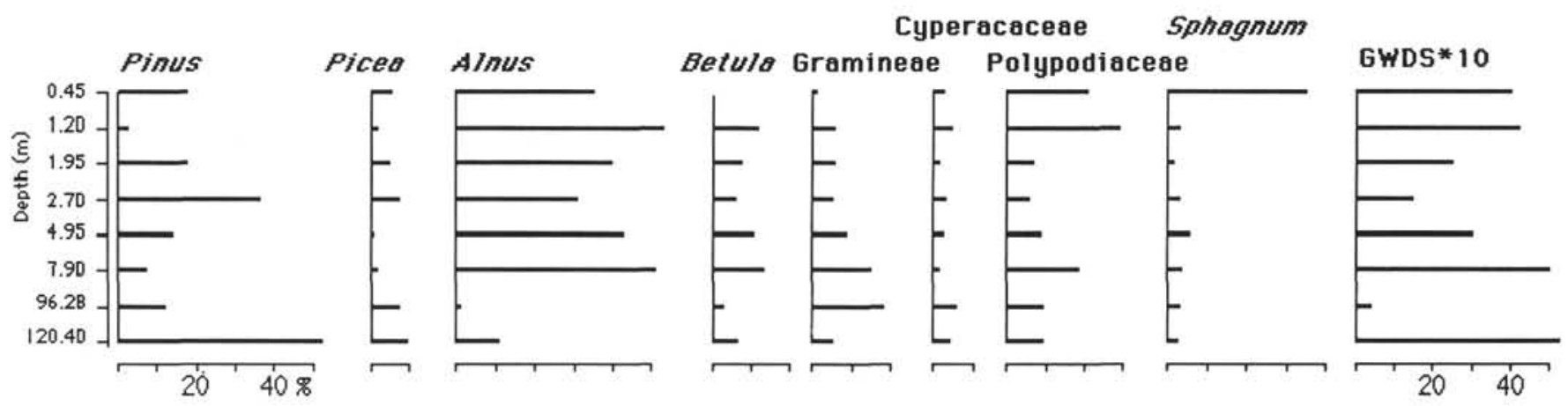

Figure 2. Pollen diagram of selected pollen types from Hole 887A. Percentages are based on the sum of all pollen identified. Concentration (pollen grains/gdws) is shown on the right. Depth (mbsf) of each sample is on the $y$-axis.

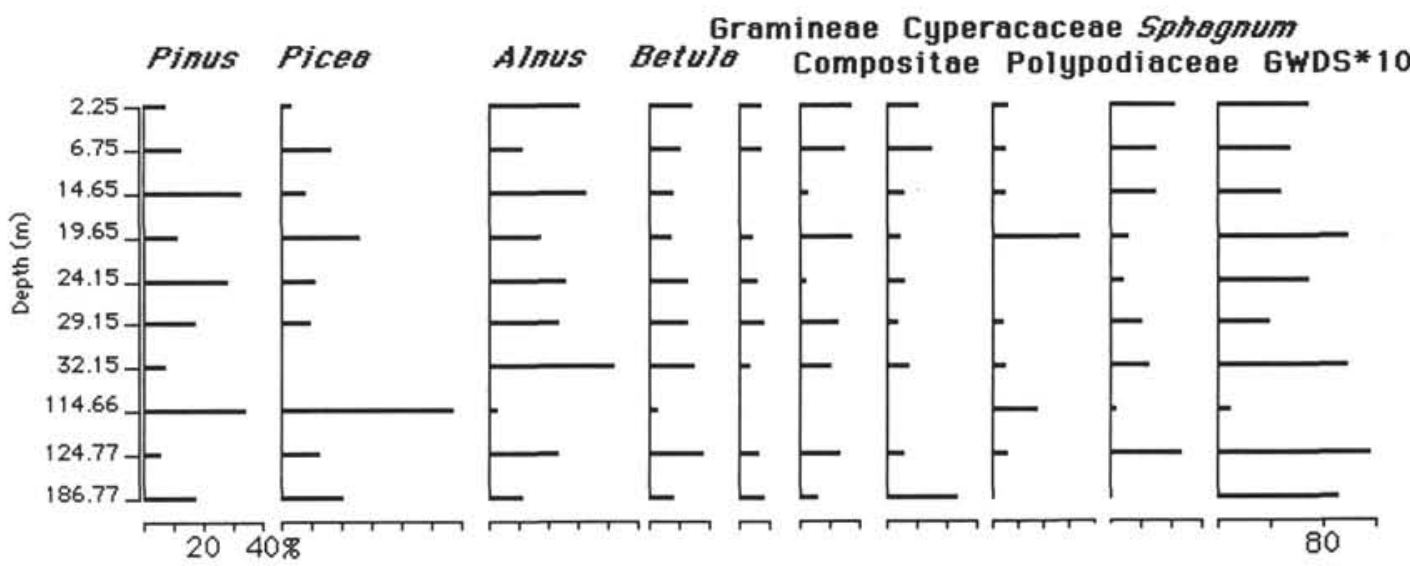

Figure 3. Pollen diagram of selected pollen types from Hole 883B. Percentages are based on the sum of all pollen identified. Concentration (pollen grains/gdws) is shown on the right. Depth (mbsf) of each sample is on the $y$-axis. 
Table 2. Pollen data, percentages, and concentration (grains/gdws) from Hole 887A.

\begin{tabular}{|c|c|c|c|c|c|c|c|c|c|c|c|c|}
\hline $\begin{array}{l}\text { Core, section: } \\
\text { Interval }(\mathrm{cm}) \text { : } \\
\text { Depth }(\mathrm{m}):\end{array}$ & $\begin{array}{c}1 \mathrm{H}-1 \\
40-48 \\
0.45\end{array}$ & $\begin{array}{c}1 \mathrm{H}-1 \\
120-123 \\
1.2\end{array}$ & $\begin{array}{c}1 \mathrm{H}-2 \\
45-48 \\
1.95\end{array}$ & $\begin{array}{c}1 \mathrm{H}-2 \\
120-123 \\
2.7\end{array}$ & $\begin{array}{c}1 \mathrm{H}-3 \\
45-48 \\
3.45\end{array}$ & $\begin{array}{l}1 \mathrm{H}-4 \\
45-48 \\
4.95\end{array}$ & $\begin{array}{c}2 \mathrm{H}-\mathrm{I} \\
120-123 \\
7.9\end{array}$ & $\begin{array}{c}2 \mathrm{H}-2 \\
47-50 \\
8.67\end{array}$ & $\begin{array}{c}11 \mathrm{H}-3 \\
111-112 \\
96.28\end{array}$ & $\begin{array}{c}11 \mathrm{H}-5 \\
120-123 \\
99.4\end{array}$ & $\begin{array}{l}13 \mathrm{H}-1 \\
45-48 \\
111.65\end{array}$ & $\begin{array}{l}13 \mathrm{H}-7 \\
20-21 \\
120.4\end{array}$ \\
\hline $\begin{array}{l}\text { Raw counts: } \\
\text { Pinus } \\
\text { Tsuga } \\
\text { Abies } \\
\text { Picea } \\
\text { Taxus } \\
\text { Alnus } \\
\text { Betula } \\
\text { Ericaceae } \\
\text { Myrica } \\
\text { Rosaceae } \\
\text { Gramineae } \\
\text { Cyperaceae } \\
\text { Compositae } \\
\text { Chenopodiaceae } \\
\text { Total pollen } \\
\text { Polypodiaceae } \\
\text { Lycopodiceae } \\
\text { Sphagnum }\end{array}$ & $\begin{array}{r}13 \\
0 \\
0 \\
5 \\
1 \\
25 \\
9 \\
0 \\
1 \\
3 \\
1 \\
2 \\
7 \\
3 \\
72 \\
15 \\
25 \\
25\end{array}$ & $\begin{array}{r}5 \\
1 \\
0 \\
3 \\
0 \\
77 \\
17 \\
4 \\
5 \\
5 \\
8 \\
7 \\
12 \\
2 \\
146 \\
42 \\
2 \\
5\end{array}$ & $\begin{array}{r}20 \\
0 \\
0 \\
6 \\
1 \\
44 \\
9 \\
1 \\
1 \\
5 \\
7 \\
2 \\
13 \\
2 \\
112 \\
8 \\
0 \\
2\end{array}$ & $\begin{array}{r}43 \\
0 \\
1 \\
9 \\
0 \\
37 \\
7 \\
0 \\
2 \\
5 \\
6 \\
4 \\
4 \\
0 \\
119 \\
7 \\
2 \\
4\end{array}$ & $\begin{array}{r}8 \\
1 \\
0 \\
1 \\
2 \\
4 \\
2 \\
1 \\
3 \\
1 \\
0 \\
0 \\
3 \\
0 \\
26 \\
7 \\
1 \\
1\end{array}$ & $\begin{array}{r}16 \\
1 \\
0 \\
1 \\
4 \\
47 \\
12 \\
1 \\
7 \\
0 \\
10 \\
3 \\
6 \\
1 \\
110 \\
10 \\
0 \\
6\end{array}$ & $\begin{array}{r}4 \\
0 \\
0 \\
1 \\
1 \\
27 \\
7 \\
0 \\
0 \\
0 \\
8 \\
1 \\
4 \\
0 \\
53 \\
10 \\
6 \\
2\end{array}$ & $\begin{array}{r}3 \\
0 \\
0 \\
0 \\
0 \\
7 \\
7 \\
0 \\
1 \\
1 \\
1 \\
0 \\
0 \\
0 \\
20 \\
4 \\
0 \\
1\end{array}$ & $\begin{array}{r}8 \\
0 \\
0 \\
5 \\
9 \\
1 \\
2 \\
0 \\
0 \\
1 \\
12 \\
4 \\
20 \\
3 \\
65 \\
6 \\
1 \\
2\end{array}$ & $\begin{array}{l}2 \\
0 \\
0 \\
0 \\
0 \\
0 \\
0 \\
0 \\
0 \\
0 \\
0 \\
0 \\
0 \\
0 \\
0 \\
2 \\
1 \\
0 \\
0\end{array}$ & $\begin{array}{l}1 \\
0 \\
0 \\
0 \\
0 \\
0 \\
0 \\
0 \\
0 \\
0 \\
0 \\
0 \\
0 \\
0 \\
1 \\
0 \\
0 \\
0\end{array}$ & $\begin{array}{r}39 \\
1 \\
2 \\
7 \\
1 \\
8 \\
5 \\
1 \\
0 \\
0 \\
4 \\
3 \\
4 \\
0 \\
75 \\
7 \\
3 \\
2\end{array}$ \\
\hline Total spores & 65 & 49 & 10 & 13 & 9 & 16 & 18 & 5 & 9 & 1 & 0 & 12 \\
\hline $\begin{array}{l}\text { Percentages: } \\
\text { Pinus } \\
\text { Tsuga } \\
\text { Abies } \\
\text { Picea } \\
\text { Taxus } \\
\text { Alnus } \\
\text { Betula } \\
\text { Ericaceae } \\
\text { Myrica } \\
\text { Rosaceae } \\
\text { Gramineae } \\
\text { Cyperaceae } \\
\text { Compositae } \\
\text { Chenopodiaceae } \\
\text { Polypodiaceae } \\
\text { Lycopodiceae } \\
\text { Sphagnum }\end{array}$ & $\begin{array}{r}18 \\
0 \\
0 \\
7 \\
1 \\
35 \\
13 \\
0 \\
1 \\
4 \\
1 \\
3 \\
10 \\
4 \\
21 \\
35 \\
35\end{array}$ & $\begin{array}{r}3 \\
1 \\
0 \\
2 \\
0 \\
53 \\
12 \\
3 \\
3 \\
3 \\
5 \\
5 \\
8 \\
1 \\
29 \\
1 \\
3\end{array}$ & $\begin{array}{r}18 \\
0 \\
0 \\
5 \\
1 \\
39 \\
8 \\
1 \\
1 \\
4 \\
6 \\
2 \\
12 \\
2 \\
7 \\
0 \\
2\end{array}$ & $\begin{array}{r}36 \\
0 \\
1 \\
8 \\
0 \\
31 \\
6 \\
0 \\
2 \\
4 \\
5 \\
3 \\
3 \\
0 \\
6 \\
2 \\
3\end{array}$ & $\begin{array}{r}31 \\
4 \\
0 \\
4 \\
8 \\
15 \\
8 \\
4 \\
12 \\
4 \\
0 \\
0 \\
12 \\
0 \\
27 \\
4 \\
4\end{array}$ & $\begin{array}{r}15 \\
1 \\
0 \\
1 \\
4 \\
43 \\
11 \\
1 \\
6 \\
0 \\
9 \\
3 \\
5 \\
1 \\
9 \\
0 \\
5\end{array}$ & $\begin{array}{r}8 \\
0 \\
0 \\
2 \\
2 \\
51 \\
13 \\
0 \\
0 \\
0 \\
15 \\
2 \\
8 \\
0 \\
19 \\
11 \\
4\end{array}$ & $\begin{array}{r}15 \\
0 \\
0 \\
0 \\
0 \\
35 \\
35 \\
0 \\
5 \\
5 \\
5 \\
0 \\
0 \\
0 \\
20 \\
0 \\
5\end{array}$ & $\begin{array}{r}12 \\
0 \\
0 \\
8 \\
14 \\
2 \\
3 \\
0 \\
0 \\
2 \\
18 \\
6 \\
31 \\
5 \\
9 \\
2 \\
3\end{array}$ & $\begin{array}{r}100 \\
0 \\
0 \\
0 \\
0 \\
0 \\
0 \\
0 \\
0 \\
0 \\
0 \\
0 \\
0 \\
0 \\
50 \\
0 \\
0\end{array}$ & $\begin{array}{r}100 \\
0 \\
0 \\
0 \\
0 \\
0 \\
0 \\
0 \\
0 \\
0 \\
0 \\
0 \\
0 \\
0 \\
0 \\
0 \\
0\end{array}$ & $\begin{array}{r}52 \\
1 \\
3 \\
9 \\
1 \\
11 \\
7 \\
1 \\
0 \\
0 \\
5 \\
4 \\
5 \\
0 \\
9 \\
4 \\
3\end{array}$ \\
\hline $\begin{array}{l}\text { Pollen concentratio } \\
\text { Total GDWS } \\
\text { Pinus } \\
\text { Tsuga } \\
\text { Abies } \\
\text { Picea } \\
\text { Taxus } \\
\text { Alnus } \\
\text { Betula } \\
\text { Ericaceae } \\
\text { Myrica } \\
\text { Rosaceae } \\
\text { Gramineae } \\
\text { Cyperaceae } \\
\text { Compositae } \\
\text { Chenopodiaceae } \\
\text { Polypodiaceae } \\
\text { Lycopodiceae } \\
\text { Sphagnum }\end{array}$ & $\begin{array}{r}\text { Ilen grai } \\
400 \\
7222 \\
0 \\
0 \\
2778 \\
556 \\
13889 \\
5000 \\
0 \\
556 \\
1667 \\
556 \\
1111 \\
3889 \\
1667 \\
8333 \\
13889 \\
13889\end{array}$ & $\begin{array}{r}\text { gdws): } \\
420 \\
1438 \\
288 \\
0 \\
863 \\
0 \\
22151 \\
4890 \\
1151 \\
1438 \\
1438 \\
2301 \\
2014 \\
3452 \\
575 \\
12082 \\
575 \\
1438\end{array}$ & $\begin{array}{r}250 \\
4464 \\
0 \\
0 \\
1339 \\
223 \\
9821 \\
2009 \\
223 \\
223 \\
1116 \\
1563 \\
446 \\
2902 \\
446 \\
1786 \\
0 \\
446\end{array}$ & $\begin{array}{r}150 \\
5420 \\
0 \\
126 \\
1134 \\
0 \\
0 \\
4664 \\
882 \\
0 \\
252 \\
630 \\
756 \\
504 \\
504 \\
0 \\
882 \\
252 \\
504\end{array}$ & $\begin{array}{r}250 \\
7692 \\
962 \\
0 \\
962 \\
1923 \\
3846 \\
1923 \\
962 \\
2885 \\
962 \\
0 \\
0 \\
2885 \\
0 \\
6731 \\
962 \\
962\end{array}$ & $\begin{array}{r}300 \\
4364 \\
273 \\
0 \\
273 \\
1091 \\
12818 \\
3273 \\
273 \\
1909 \\
0 \\
2727 \\
818 \\
1636 \\
273 \\
2727 \\
0 \\
1636\end{array}$ & $\begin{array}{r}500 \\
3774 \\
0 \\
0 \\
943 \\
943 \\
25472 \\
6604 \\
0 \\
0 \\
0 \\
7547 \\
943 \\
3774 \\
0 \\
9434 \\
5660 \\
1887\end{array}$ & $\begin{array}{r}300 \\
4500 \\
0 \\
0 \\
0 \\
0 \\
10500 \\
10500 \\
0 \\
1500 \\
1500 \\
1500 \\
0 \\
0 \\
0 \\
6000 \\
0 \\
1500\end{array}$ & $\begin{array}{r}40 \\
492 \\
0 \\
0 \\
308 \\
554 \\
62 \\
123 \\
0 \\
0 \\
62 \\
738 \\
246 \\
1231 \\
185 \\
369 \\
62 \\
123\end{array}$ & $\begin{array}{r}1 \\
100 \\
0 \\
0 \\
0 \\
0 \\
0 \\
0 \\
0 \\
0 \\
0 \\
0 \\
0 \\
0 \\
0 \\
50 \\
0 \\
0\end{array}$ & $\begin{array}{r}1 \\
100 \\
0 \\
0 \\
0 \\
0 \\
0 \\
0 \\
0 \\
0 \\
0 \\
0 \\
0 \\
0 \\
0 \\
0 \\
0 \\
0\end{array}$ & $\begin{array}{r}50 \\
2600 \\
67 \\
133 \\
467 \\
67 \\
533 \\
333 \\
67 \\
0 \\
0 \\
267 \\
200 \\
267 \\
0 \\
467 \\
200 \\
133\end{array}$ \\
\hline
\end{tabular}

Note: grains/gdws $=$ grains $/ g$ dry weight sediment . 
Table 3. Pollen data, percentages, and concentration (grains/gdws) from Hole 883B.

\begin{tabular}{|c|c|c|c|c|c|c|c|c|c|c|c|c|c|c|c|c|c|}
\hline $\begin{array}{l}\text { Core, section: } \\
\text { Interval (cm): } \\
\text { Depth }(\mathrm{m}):\end{array}$ & $\begin{array}{c}1 \mathrm{H}-5 \\
75-79 \\
2.25\end{array}$ & $\begin{array}{c}1 \mathrm{H}-5 \\
75-79 \\
6.75\end{array}$ & $\begin{array}{c}2 \mathrm{H}-2 \\
75-79 \\
10.15 \\
\end{array}$ & $\begin{array}{c}2 \mathrm{H}-5 \\
75-79 \\
14.65 \\
\end{array}$ & $\begin{array}{c}3 \mathrm{H}-2 \\
75-79 \\
19.65\end{array}$ & $\begin{array}{l}3 \mathrm{H}-5 \\
75-78 \\
24.15\end{array}$ & $\begin{array}{c}4 \mathrm{H}-2 \\
75-78 \\
29.15 \\
\end{array}$ & $\begin{array}{l}4 \mathrm{H}-4 \\
75-79 \\
32.15 \\
\end{array}$ & $\begin{array}{l}10 \mathrm{H}-2 \\
75-79 \\
85.16\end{array}$ & $\begin{array}{l}11 \mathrm{H}-2 \\
76-80 \\
95.65\end{array}$ & $\begin{array}{l}11 \mathrm{H}-4 \\
74-79 \\
98.64\end{array}$ & $\begin{array}{l}12 \mathrm{H}-2 \\
76-80 \\
105.16\end{array}$ & $\begin{array}{l}12 \mathrm{H}-5 \\
76-80 \\
109.66\end{array}$ & $\begin{array}{l}13 \mathrm{H}-2 \\
76-80 \\
114.66\end{array}$ & $\begin{array}{l}13 \mathrm{H}-5 \\
76-80 \\
119.16 \\
\end{array}$ & $\begin{array}{l}14 \mathrm{H}-2 \\
76-80 \\
124.77\end{array}$ & $\begin{array}{c}19 \mathrm{H}-5 \\
137-138 \\
176.77 \\
\end{array}$ \\
\hline $\begin{array}{l}\text { Raw counts: } \\
\text { Pinus } \\
\text { Tsuga } \\
\text { Abies } \\
\text { Picea } \\
\text { Alnus } \\
\text { Betula } \\
\text { Ericaceae } \\
\text { Myrica } \\
\text { Rosaceae-type } \\
\text { Gramineae } \\
\text { Cyperaceae } \\
\text { Compositae } \\
\text { Chenopodiaceae } \\
\text { Total pollen } \\
\text { Polypodiaceae } \\
\text { Lycopodiaceae } \\
\text { Sphagnum }\end{array}$ & $\begin{array}{r}6 \\
0 \\
0 \\
3 \\
23 \\
11 \\
3 \\
0 \\
0 \\
6 \\
13 \\
8 \\
1 \\
74 \\
14 \\
3 \\
3 \\
26\end{array}$ & $\begin{array}{r}10 \\
1 \\
0 \\
13 \\
9 \\
8 \\
0 \\
0 \\
4 \\
6 \\
12 \\
12 \\
0 \\
75 \\
30 \\
21 \\
45\end{array}$ & $\begin{array}{l}0 \\
0 \\
0 \\
1 \\
0 \\
1 \\
0 \\
0 \\
0 \\
1 \\
1 \\
1 \\
0 \\
5 \\
3 \\
4 \\
2\end{array}$ & $\begin{array}{r}11 \\
0 \\
0 \\
3 \\
11 \\
3 \\
1 \\
0 \\
0 \\
0 \\
1 \\
2 \\
0 \\
32 \\
7 \\
4 \\
11\end{array}$ & $\begin{array}{r}9 \\
1 \\
1 \\
20 \\
13 \\
6 \\
2 \\
0 \\
0 \\
4 \\
13 \\
4 \\
1 \\
74 \\
500 \\
66 \\
47\end{array}$ & $\begin{array}{r}15 \\
0 \\
0 \\
6 \\
14 \\
7 \\
1 \\
1 \\
0 \\
3 \\
1 \\
3 \\
1 \\
52 \\
13 \\
22 \\
38\end{array}$ & $\begin{array}{r}12 \\
1 \\
0 \\
7 \\
16 \\
9 \\
0 \\
0 \\
0 \\
6 \\
9 \\
3 \\
2 \\
2 \\
67 \\
20 \\
3 \\
26 \\
\end{array}$ & $\begin{array}{r}12 \\
0 \\
0 \\
2 \\
25 \\
65 \\
25 \\
1 \\
1 \\
2 \\
6 \\
17 \\
12 \\
12 \\
5 \\
152 \\
39 \\
4 \\
47\end{array}$ & $\begin{array}{l}5 \\
0 \\
0 \\
2 \\
0 \\
1 \\
0 \\
0 \\
0 \\
0 \\
0 \\
0 \\
0 \\
8 \\
0 \\
0 \\
0\end{array}$ & $\begin{array}{l}4 \\
0 \\
0 \\
2 \\
0 \\
2 \\
0 \\
0 \\
0 \\
0 \\
0 \\
0 \\
0 \\
8 \\
2 \\
0 \\
0\end{array}$ & $\begin{array}{r}24 \\
0 \\
0 \\
2 \\
1 \\
0 \\
0 \\
0 \\
0 \\
0 \\
0 \\
0 \\
0 \\
27 \\
10 \\
0 \\
0\end{array}$ & $\begin{array}{r}6 \\
0 \\
0 \\
6 \\
0 \\
0 \\
0 \\
0 \\
0 \\
0 \\
0 \\
0 \\
0 \\
12 \\
8 \\
0 \\
0\end{array}$ & $\begin{array}{l}1 \\
0 \\
0 \\
0 \\
0 \\
0 \\
0 \\
0 \\
0 \\
0 \\
0 \\
0 \\
0 \\
1 \\
2 \\
0 \\
1\end{array}$ & $\begin{array}{r}12 \\
0 \\
0 \\
20 \\
1 \\
1 \\
0 \\
0 \\
0 \\
0 \\
0 \\
0 \\
0 \\
34 \\
21 \\
0 \\
1\end{array}$ & $\begin{array}{l}3 \\
0 \\
0 \\
2 \\
0 \\
0 \\
0 \\
0 \\
0 \\
0 \\
0 \\
0 \\
0 \\
5 \\
0 \\
0 \\
1\end{array}$ & $\begin{array}{r}4 \\
0 \\
0 \\
9 \\
17 \\
13 \\
1 \\
1 \\
1 \\
5 \\
10 \\
4 \\
0 \\
70 \\
17 \\
4 \\
31\end{array}$ & $\begin{array}{r}6 \\
0 \\
0 \\
7 \\
4 \\
3 \\
1 \\
0 \\
0 \\
3 \\
2 \\
8 \\
0 \\
34 \\
4 \\
0 \\
1\end{array}$ \\
\hline Total spores & 43 & 96 & 9 & 22 & 613 & 73 & 49 & 90 & 0 & 2 & 10 & 8 & 3 & 22 & 1 & 52 & 5 \\
\hline $\begin{array}{l}\text { Percentages: } \\
\text { Pinus } \\
\text { Tsuga } \\
\text { Abies } \\
\text { Picea } \\
\text { Alnus } \\
\text { Betula } \\
\text { Ericaceae } \\
\text { Myrica } \\
\text { Rosaceae-type } \\
\text { Gramineac } \\
\text { Cyperaceae } \\
\text { Compositae } \\
\text { Chenopodiaceae } \\
\text { Polypodiaceac } \\
\text { Lycopodiaceae } \\
\text { Sphagnum }\end{array}$ & $\begin{array}{r}8 \\
0 \\
0 \\
4 \\
31 \\
15 \\
4 \\
0 \\
0 \\
8 \\
18 \\
11 \\
1 \\
12 \\
3 \\
22\end{array}$ & $\begin{array}{r}13 \\
1 \\
0 \\
17 \\
12 \\
11 \\
0 \\
0 \\
5 \\
8 \\
16 \\
16 \\
0 \\
10 \\
7 \\
16\end{array}$ & $\begin{array}{r}0 \\
0 \\
0 \\
20 \\
0 \\
20 \\
0 \\
0 \\
0 \\
20 \\
20 \\
20 \\
0 \\
2 \\
2 \\
1\end{array}$ & $\begin{array}{r}34 \\
0 \\
0 \\
9 \\
34 \\
9 \\
3 \\
0 \\
0 \\
0 \\
3 \\
6 \\
0 \\
10 \\
6 \\
16\end{array}$ & $\begin{array}{r}12 \\
1 \\
1 \\
27 \\
18 \\
8 \\
3 \\
0 \\
0 \\
5 \\
18 \\
5 \\
1 \\
67 \\
9 \\
6\end{array}$ & $\begin{array}{r}29 \\
0 \\
0 \\
12 \\
27 \\
13 \\
2 \\
2 \\
0 \\
6 \\
2 \\
6 \\
2 \\
2 \\
3 \\
5\end{array}$ & $\begin{array}{r}18 \\
1 \\
0 \\
10 \\
24 \\
13 \\
0 \\
0 \\
0 \\
9 \\
13 \\
4 \\
3 \\
8 \\
1 \\
11\end{array}$ & $\begin{array}{r}8 \\
0 \\
0 \\
1 \\
43 \\
16 \\
1 \\
1 \\
1 \\
4 \\
11 \\
8 \\
3 \\
11 \\
1 \\
13\end{array}$ & $\begin{array}{r}63 \\
0 \\
0 \\
25 \\
0 \\
13 \\
0 \\
0 \\
0 \\
0 \\
0 \\
0 \\
0 \\
0 \\
0 \\
0\end{array}$ & $\begin{array}{r}50 \\
0 \\
0 \\
25 \\
0 \\
25 \\
0 \\
0 \\
0 \\
0 \\
0 \\
0 \\
0 \\
20 \\
0 \\
0\end{array}$ & $\begin{array}{r}89 \\
0 \\
0 \\
7 \\
4 \\
0 \\
0 \\
0 \\
0 \\
0 \\
0 \\
0 \\
0 \\
21 \\
0 \\
0\end{array}$ & $\begin{array}{r}50 \\
0 \\
0 \\
50 \\
0 \\
0 \\
0 \\
0 \\
0 \\
0 \\
0 \\
0 \\
0 \\
14 \\
0 \\
0\end{array}$ & $\begin{array}{r}100 \\
0 \\
0 \\
0 \\
0 \\
0 \\
0 \\
0 \\
0 \\
0 \\
0 \\
0 \\
0 \\
8 \\
0 \\
4\end{array}$ & $\begin{array}{r}35 \\
0 \\
0 \\
59 \\
3 \\
3 \\
0 \\
0 \\
0 \\
0 \\
0 \\
0 \\
0 \\
35 \\
0 \\
2\end{array}$ & $\begin{array}{r}60 \\
0 \\
0 \\
40 \\
0 \\
0 \\
0 \\
0 \\
0 \\
0 \\
0 \\
0 \\
0 \\
0 \\
0 \\
2\end{array}$ & $\begin{array}{r}6 \\
0 \\
0 \\
13 \\
24 \\
19 \\
1 \\
1 \\
1 \\
7 \\
14 \\
6 \\
0 \\
13 \\
3 \\
24\end{array}$ & $\begin{array}{r}18 \\
0 \\
0 \\
21 \\
12 \\
9 \\
3 \\
0 \\
0 \\
9 \\
9 \\
6 \\
24 \\
0 \\
2 \\
0 \\
1\end{array}$ \\
\hline $\begin{array}{l}\text { Concentration (poll } \\
\text { Total gdws } \\
\text { Pinus } \\
\text { Tsuga } \\
\text { Abies } \\
\text { Picea } \\
\text { Alinus } \\
\text { Betula } \\
\text { Ericaceae } \\
\text { Myrica } \\
\text { Rosaceae-type } \\
\text { Gramineae } \\
\text { Cyperaceae } \\
\text { Compositae } \\
\text { Chenopodiaceae } \\
\text { Polypodiaceae } \\
\text { Lycopodiaceae } \\
\text { Sphagnum }\end{array}$ & $\begin{array}{r}\text { rains/gdv } \\
70 \\
568 \\
0 \\
0 \\
284 \\
2176 \\
1041 \\
284 \\
0 \\
0 \\
568 \\
1230 \\
757 \\
95 \\
840 \\
210 \\
1540\end{array}$ & $\begin{array}{r}56 \\
747 \\
75 \\
0 \\
971 \\
672 \\
597 \\
0 \\
0 \\
0 \\
299 \\
448 \\
896 \\
896 \\
0 \\
560 \\
392 \\
896\end{array}$ & $\begin{array}{r}20 \\
0 \\
0 \\
0 \\
0 \\
400 \\
0 \\
400 \\
0 \\
0 \\
0 \\
400 \\
400 \\
400 \\
0 \\
40 \\
40 \\
20\end{array}$ & $\begin{array}{r}50 \\
1700 \\
0 \\
0 \\
450 \\
1700 \\
450 \\
150 \\
0 \\
0 \\
0 \\
150 \\
300 \\
0 \\
500 \\
300 \\
800\end{array}$ & $\begin{array}{r}100 \\
1200 \\
100 \\
100 \\
2700 \\
1800 \\
800 \\
300 \\
0 \\
0 \\
500 \\
500 \\
1800 \\
500 \\
100 \\
6700 \\
900 \\
600\end{array}$ & $\begin{array}{r}70 \\
2030 \\
0 \\
0 \\
840 \\
1890 \\
910 \\
140 \\
140 \\
0 \\
420 \\
140 \\
420 \\
140 \\
140 \\
210 \\
350\end{array}$ & $\begin{array}{r}40 \\
720 \\
40 \\
0 \\
400 \\
960 \\
520 \\
0 \\
0 \\
0 \\
360 \\
520 \\
160 \\
120 \\
320 \\
40 \\
440\end{array}$ & $\begin{array}{r}100 \\
800 \\
0 \\
0 \\
100 \\
4300 \\
1600 \\
100 \\
100 \\
100 \\
400 \\
1100 \\
800 \\
300 \\
1100 \\
100 \\
1300\end{array}$ & $\begin{array}{r}16 \\
1008 \\
0 \\
0 \\
0 \\
400 \\
0 \\
208 \\
0 \\
0 \\
0 \\
0 \\
0 \\
0 \\
0 \\
0 \\
0 \\
0\end{array}$ & $\begin{array}{r}5 \\
250 \\
0 \\
0 \\
125 \\
0 \\
125 \\
0 \\
0 \\
0 \\
0 \\
0 \\
0 \\
0 \\
100 \\
0 \\
0\end{array}$ & $\begin{array}{r}10 \\
890 \\
0 \\
0 \\
70 \\
40 \\
0 \\
0 \\
0 \\
0 \\
0 \\
0 \\
0 \\
0 \\
210 \\
0 \\
0\end{array}$ & $\begin{array}{r}1 \\
50 \\
0 \\
0 \\
50 \\
0 \\
0 \\
0 \\
0 \\
0 \\
0 \\
0 \\
0 \\
0 \\
14 \\
0 \\
0\end{array}$ & $\begin{array}{r}1 \\
100 \\
0 \\
0 \\
0 \\
0 \\
0 \\
0 \\
0 \\
0 \\
0 \\
0 \\
0 \\
0 \\
8 \\
0 \\
4\end{array}$ & $\begin{array}{r}10 \\
350 \\
0 \\
0 \\
590 \\
30 \\
30 \\
0 \\
0 \\
0 \\
0 \\
0 \\
0 \\
0 \\
350 \\
0 \\
0\end{array}$ & $\begin{array}{r}10 \\
600 \\
0 \\
0 \\
400 \\
0 \\
0 \\
0 \\
0 \\
0 \\
0 \\
0 \\
0 \\
0 \\
0 \\
0 \\
0\end{array}$ & $\begin{array}{r}118 \\
708 \\
0 \\
0 \\
1534 \\
2832 \\
2242 \\
118 \\
118 \\
118 \\
826 \\
1652 \\
708 \\
0 \\
1534 \\
354 \\
2832\end{array}$ & $\begin{array}{r}94 \\
1692 \\
0 \\
0 \\
0 \\
1974 \\
1128 \\
846 \\
282 \\
0 \\
0 \\
046 \\
864 \\
5256 \\
226 \\
0 \\
188 \\
0 \\
94\end{array}$ \\
\hline
\end{tabular}

